\title{
HUBUNGAN ANTARA REACTION TIME DAN KEKUATAN MAKSIMAL OTOT LENGAN DENGAN KECEPATAN PUKULAN PADA CABANG OLAHRAGA TINJU
}

\author{
Hanif Abdurrojak, Iman Imanudin
}

Program Studi Ilmu keolahragaan

Departemen Pendidikan Kesehatan dan Rekreasi

Fakultas Pendidikan Olahraga dan Kesehatan

Universitas Pendidikan Indonesia, Jl. Dr. Setiabudhi No. 299 Bandung

Email: hanifabdurrojak@gmail.com

\begin{abstract}
Abstrak
Tujuan dari penelitian ini untuk mengkaji sejauh mana hubungan komponen-komponen kondisi fisik seperti reaction time dan kekuatan maksimal otot lengan dengan kecepatan pukulan pada cabang olahraga tinju. Metode yang digunakan adalah deskriptif korelasi. Untuk menganalisis data menggunakan uji korelasi, agar diketahui hubungan antara reaction time dan kekuatan maksimal dengan kecepatan pukulan pada cabang olahraga tinju. Populasi pada penelitian ini adalah atlet rumah cemara boxing camp. Sampel diambil menggunakan teknik sampling jenuh dimana sampel diambil dari keseluruhan jumlah populasi yang berjumlah sebanyak 8 orang. Instrument yang digunakan yaitu, alat discriminative reaction test of multiple performance type untuk tes reaction time, barbell untuk tes kekuatan maksimal otot lengan dengan menggunakan tes bench press, stopwatch, camera dan software kinovea untuk tes kecepatan pukulan. Hasil pengolahan data menunjukan bahwa reaction time tidak memiliki hubungan dengan kecepatan pukulan pada cabang olahraga tinju, kekuatan maksimal memiliki hubungan dengan kecepatan pukulan pada cabang olahraga tinju. Hasil penelitian ini diperoleh tidak terdapat hubungan antara reaction time dengan kecepatan pukulan pada cabang olahraga tinju, dan terdapat hubungan antara kekuatan maksimal dengan kecepatan pukulan pada cabang olahraga tinju.
\end{abstract}

Kata kunci: Waktu Reaksi, Kekuatan Maksimal, Komponen Kondisi Fisik, Kecepatan Pukulan, Tinju.

\section{PENDAHULUAN}

Dalam olahraga tinju, pukulan memiliki peran yang sangat penting. Berbeda dengan cabang olahraga bela diri yang lain, tinju hanya mengandalkan pukulan untuk mematikan lawan. Ada empat jenis pukulan dalam tinju seperti Jab, straight, Hook, dan uppercut, dimana dari keempat pukulan ini salah satunya selalu dijadikan sebagai pukulan seorang petinju untuk mejatuhkan/memukul Knock out. Seperti Mike Tison yang sering memukul K.O dengan pukulan Hook yang menjadi andalannya.

Komponen kondisi fisik didalam olahraga tinju sangatlah dibutuhkan untuk menunjang beberapa teknik dan bertinju seorang atlet, karena olahraga tinju 
merupakan olahraga beladiri berinterval dan durasi waktu yang panjang sehingga memerlukan kondisi fisik yang sangat baik. Baik itu daya tahan, kecepatan, kekuatan, dan fleksibilitas.

Reaction time dalam tinju diperlukan untuk kecepatan gerak atau aksi memukul baik yang diawali stimulus atau tanpa stimulus. Reaction time digunakan pada saat lawan terbuka pertahanan atau ada celah untuk menyerang sehingga respon yang cepat untuk menyerang sangatlah diperlukan dalam tinju, baik itu dalam keadaan menyerang ataupun menghindar. (Iman imanudin, 2014)

Untuk menghasilkan pukulan yang kuat, atlet harus melatih kekuatan tangannya. Dalam ilmu kondisi fisik, kekuatan merupakan salah satu komponen yang sangat penting untuk menunjang kekuatan pukulan secara maksimal. Kekuatan maksimal diperlukan untuk menunjang daya tahan kekuatan dan kekuatan yang cepat sehingga petinju bisa melakukan pukulan yang cepat, kuat, dan berulang ulang. (Iman imanudin, 2014)

Dari komponen-komponen diatas dalam olahraga tinju untuk menunjang ketika melancarkan serang dan untuk mematikan lawannya, maka harus memiliki pukulan yang keras, cepat, dan bereaksi cepat ketika melihat celah yang terbuka untuk menyerang lawan.

Dari penelitian penelitian Ruddock, Alan D. Csci., dkk. (2016). Olahraga ini merupakan olahraga intensitas tinggi yang memerlukan karakteristik fisik mumpuni sebagai syarat untuk meraih kesuksesan dalam setiap performa. Perhatian serius pun telah diberikan terhadap aspek medis dan juga resiko kesehatan dari keikut sertaan seorang atlet dalam latihan maupun kompetisi. Akan tetapi, belum terdapat sebuah sumber penelitian tentang ilmu keolahragaan terapan yang meliputi secara luas mengenai persiapan seorang petinju profesional dalam partisipasinya pada pertandingan. Pada penelitian ini, penulis mempersembahkan sebuah hasil penelitian yang meliputi aspek fisiologi, kekuatan, dan conditioning dalam bentuk dasar pengetahuan untuk orang-orang yang terlibat dalam persiapan petinju profesional dalam menghadapi pertandingan. Berangkat dari uraian diatas hal ini yang menjadikan dasar peneliti untuk meneliti "hubungan reaction time dan kekuatan maksimal otot lengan dengan kecepatan pukulan dalam olahraga tinju". Dengan harapan bisa membantu pelatih untuk meningkatkan kemampuan atlet sehingga dapat menentukan program latihan yang sesuai untuk mendapatkan pukulan yang baik.

\section{METODE}

Penelitian ini adalah jenis penelitian pendekatan kuantitatif. Menurut Suhar Saputra, Uhar (2012) penelitian kuantitatif adalah penelitian yang menggunakan angka-angka yang dijumlah sebagai data yang kemudian dianalisis. Pada penelitian ini metode yang digunakan adalah metode deskriptif korelasi. Analisis data yang digunakan pada penelitian ini adalah korelasi, korelasi yaitu menjelaskan tentang hubungan antara dua atau lebih variabel yang diteliti. Menurut Arikunto Suharismi (2006), koefesien korelasi adalah suatu alat statistic yang dapat digunakan untuk membandingkan hasil pengukuran dua variabel yang berbeda agar dapat menentukan tingkat hubungan antara variabel-variabel ini. Dimana dalam melaksanakan survei biasanya dibuat suatu 
analisis kuantitatif terhadap data yang telah dikumpulkan. Astuti, Ria (2016). Pada penelitian ini peneliti akan mengungkap hubungan reaction time dan kekuatan maksimal dengan kecepatan pukulan dalam olahraga tinju. Sehingga desain penelitian yang digunakan adalah korelasi.

Populasi untuk penelitian ini adalah atlet tinju dari sasana Rumah Cemara Boxing Camp yang berjumlah 8 orang. Dengan demikian jumlah instrument yang akan digunakan dalam penelitian akan tergantung pada jumlah variabel yang akan diteliti.

Berkaitan dengan penelitian ini maka instrument yang digunakan dalam penelitian ini adalah sebagai berikut.

Tes Reaction Time

Discriminative reactiaon test of multiple performance type. Yang bertempat di Lab Universitas Pendidikan Indonesia, Fakultas Pendidikan Olahraga dan Kesehatan. Untuk mengetahui seberapa baik reaksi yang atlet miliki.

Tes Kekuatan Maksimal Otot Lengan

Menggunakan barbell dengan tes Bench press 1 RM. Untuk mengukur kekuatan maksimal.

Tes Kecepatan Pukulan

Menggunakan alat stopwatch dan kamera, dengan Memukul secepat mungkin dan sebanyak mungkin dengan durasi waktu selama 4 detik.

\section{Software Kinovea}

Untuk menghitung seberapa banyak pukulan atlet dari hasil video pengetesan kecepatan pukulan dalam waktu 4 detik.

\section{HASIL DAN PEMBAHASAN}

Hasil penelitian yang didapat dari pengumpulan data, setelah itu data yang telah didapat dari sampel akan diolah menggunakan SPSS V.21 dan akan dijadikan dalam bentuk tabel. Penelitian ini merupakan penelitian kuantitatif. Pengumpulan data dalam penelitian ini diperoleh dengan cara melakukan tes reaction time, kekuatan maksimal dan tes kecepatan pukulan.

Penelitian ini menggunakan sampel 8 orang atlet dari sasana rumah cemara boxing camp. Sampel tersebut telah di tes reaction time, kekuatan maksimal dan tes kecepatan pukulan.

Pengolahan data dilakukan dengan cara mengolah data mentah yang telah terkumpul dan ditarik kesimpulan. Adapun hasil dari pengolahan dan analisis peneliti uraikan padatabel berikut:

Table 1 Nilai Rata-rata dan Simpangan baku

\begin{tabular}{|l|l|l|}
\hline Varibel & $\begin{array}{l}\text { Rata- } \\
\text { rata }\end{array}$ & $\begin{array}{l}\text { Simpangan } \\
\text { baku }\end{array}$ \\
\hline Reaction time & 50.13 & 9.99 \\
\hline $\begin{array}{l}\text { Kekuatan } \\
\text { maksimal otot } \\
\text { lengan }\end{array}$ & $65 \mathrm{~kg}$ & 14.39 \\
\hline $\begin{array}{l}\text { Kecepatan } \\
\text { pukulan }\end{array}$ & $15 \mathrm{kali}$ & 1.03 \\
\hline
\end{tabular}

Berdasarkan tabel 1 . reaction time memiliki rata-rata $=50.127538$, dan simpangan baku $=9.9932659$, kekuatan maksimal otot lengan memiliki rata-rata $=$ $65 \mathrm{~kg}$ dan simpangan baku 14.39, dan kecepatan pukulan memiliki rata-rata $=15$ kali dan simpangan baku 1.30.

Apabila telah diketahui nilai rata-rata dan simpangan baku dari data tersebut, maka langkah selanjutnya adalah menganalisis data dengan cara uji normalitas untuk mengetahui apakah data berdistribusi normal atau tidak, apabila data berdistribusi normal maka dilakukan uji korelasi menggunakan korelasi person 
(korelasi person digunakan jika data berdistribusi normal) dan terakhir dilakukan uji regresi untuk mengetahui seberapa erat hubungan antara variabel independen dan variabel dependen.

Uji normalitas dilakukan untuk mengetahui variabel yang akan dianalis itu berdistribusi normal atau tidak. Peneliti menggunakan teknik analisis Kolmogorov smirnov untuk mengetahui normalitas data.

Untuk reaction time hasil uji normalitas $\mathrm{p}=0.627>0.05$, data reaction time berdistribusi normal. Untuk kekuatan maksimal otot lengan $p=0.750>0.05$, data kekuatan maksimal berdistribusi normal. Dan untuk kecepatan pukulan $\mathrm{p}=$ $0.832>0.05$, data kecepatan pukulan berdistribusi normal.

Uji korelasi dilakukan untuk mengetahui apakah terdapat hubungan antara reaction time (variabel bebas) dan kekuatan maksimal (variabel bebas) dan kecepatan pukulan (variabel terikat) yang diteliti.

Setelah data melewati tahap uji normalitas, dapat diketahui bahwa data berdistribusi normal. Apabila data berdistribusi normal maka menggunakan koefisien korelasi pearson.

Nilai korelasi reaction time dengan kecepatan pukulan pada cabang olahraga tinju adalah, $\mathrm{r}=0.602, \mathrm{p}=0.114<0.05$, maka Ho diterima. Tidak terdapat hubungan yang positif dan signifikan antara reaction time dengan kecepatan pukulan dalam cabang olahraga tinju.

Nilai korelasi kekuatan maksimal otot lengan dengan kecepatan pukulan dalam cabang olahraga tinju adalah $\mathrm{r}=0.815, \mathrm{p}=$ $0.14<0.05$, Ho ditolak. Terdapat hubungan yang positif dan signifikan antara kekuatan maksimal otot lengan dengan kecepatan pukulan dalam cabang olahraga tinju. Semakin tinggi nilai kekuatan maksimal maka akan semakin tinggi nilai kecepatan pukulan, sebaliknya semakin rendah nilai kekuatan maksimal makan akan semakin rendah nilai kecepatan pukulan.

Diskusi temuan ini menguraikan tentang perihal permasalahan dan penemuan yang muncul selama melakukan penelitian hubungan antara reaction time dan kekuatan maksimal dengan kecepatan pukulan dalam cabang olahraga tinju berlangsung. Berikut ini beberapa penemuan yang dirumuskan peneliti sebagai berikut:

Gambaran hasil penelitian yang telah dilakukan oleh peneliti yang ingin mengetahui hubungan antara reaction time dengan kecepatan pukulan dalam cabang olahraga tinju. Hasil dari penelitian ini adalah sebagai berikut:

Tidak terdapat hubungan yang signifikan antara reaction time dengan kecepatan pukulan.

Karena reaction time yang bekerja adalah syaraf atau perintah yang mencakup dari terjadinya rangsangan sampai saat terjadinya kontraksi otot yang pertama. Sedangkan kecepatan pukulan yang bekerja adalah otot atau sudah ke pelaksanaan. Tetapi kedua komponen ini termasuk kedalam komponen kondisi fisik. Dalam buku Imanudin Iman (2014:87 dan 92)

Terdapat hubungan yang signifikan. Karena kekuatan maksimal otot lengan termasuk kedalam kondisi fisik untuk menujang kekuatan dan cepatnya pukulan.

Hasil analisis data yang didapat dari pengolahan data, sesuai dengan hipotesis yang telah diajukan oleh peneliti yaitu tidak terdapat hubungan yang signifikan antara reaction time dengan kecepatan pukulan dalam cabang olahraga tinju. Dan terdapat hubungan yang signifikansi antara kekuatan 
maksimal otot lengan dengan kecepatan pukulan.

\section{KESIMPULAN}

Berdasarkan hasil pengolahan dan analisis data yang telah diuraikan pada BAB IV, dapat dijabarkan kesimpulan dari hasil penelitian yang dilakukan. Adapun simpulan yang diperoleh adalah tidak terdapat hubungan yang signifikan antara reaction time dengan kecepatan pukulan dalam cabang olahraga tinju. Dikarenakan reaction time dan kecepatan pukulan cara kerjanya berbeda, karena reaction time yang bekerja adalah syaraf atau perintah untuk melakukan gerakan yang mencakup waktu dari terjadinya rangsangan sampai saat terjadinya kontraksi otot yang pertama. Sedangkan kecepatan pukulan yang bekerja adalah otot atau sudah pada tahap pelaksanaan dari awal kontraksi otot sampai selesai.T
Selanjutnya terdapat hubungan yang signifikan antara kekuatan maksimal otot lengan dengan kecepatan pukulan dalam cabang olahraga tinju. Peneliti menyarankan untuk pelatih agar lebih memperhatikan setiap unsur-unsur komponen kondisi fisik seperti reaction time dan kekuatan maksimal yang menujang dalam melakukan pukulan dan menyerang.

Bagi peneliti selanjutnya yang akan meneliti khususnya tentang cabang olahraga beladiri. Masih banyak beberapa hal yang perlu diperbaiki dan dilengkapi. Contohnya pada penelitian ini membahas tentang unsur komponen kondisi fisik seperti reaction time dan kekuatan maksimal untuk menunjang kemampuan atlet dicabang olahraga beladiri. Direkomendasikan untuk peneliti selanjutnya meneliti tentang daya tahan, fleksibilitas dan lainya yang belum diteliti. Karena komponen kondisi fisik harus terpenuhi untuk menunjang dalam aktivitas beladiri.

\section{DAFTAR PUSTAKA}

Arikunto, Suharismi. (2006). Prosedur Penelitian Suatu Pendekatan Praktik. Jakarta: PT Rineka Cipta.

Baley, James A. 1986. Pedoman Atlet Teknik Peningkatan Ketangkasan dan Stamina. Semarang : Bahasa Prise

Bompa, T. O. (1999). Periodezation Training For Sport. York, University

Dr. Kardjono. (2008). Modul Pembinaan Kondisi Fiisik. Bandung: Universitas Pendidikan Indonesia.

Harsono. (1988). Coaching dan Aspek-Aspek Psikologi dalam Coaching. Bandung: CV. Tambak Kusuma

Hatmaker, M. \& Werner, D. (2004). Boxing Mastery (Advanced Technique, Tactics and Strategies From The Sweet Science). California: Sandiego.

Imanudin, I. (2014). Bahan Ajar Ilmu Kepelatihan Olahraga. Bandung: I Imanudin M. Pd. 
Rahayu, N. I. \& Suherman, A. (2014). Modul Statistika untuk Ilmu Keolahragaan. edisi kedua, Bandung :

Ruddock, Alan D. Csci., dkk. (2016). Strength and Conditioning for Professional Boxing: Recommendations for Physical Preparation. Strength \& Conditioning Journal, $38(3)$.

Sugiyono. (2010). Metode Penelitian Pendidikan (Pendekatan Kuantitatif, Kualitatif, dan $R \& D)$. Bandung: Alfabet.

Suharno HP.1985. Ilmu Kepelatihan Olahraga. Yogyakarta.1978. Ilmu Coaching Umum. Yogyakarta: Yayasan STO

Hasan, Zulkifli. (2014). Jurnal. Hubungan koordinasi mata-kaki dan kecepatan reaksi dengan keterampilan juggling freestyle soccer (studi deskriptif pada komunitas freestyle soccer Bandung). Bandung: Universitas Pendidikan Indonesia.

Juhanis. (2013). Analisis Korelasi Kecepatan Reaksi Kaki dan Daya Ledak Tungkai dengan Kemampuan Lari 100 Meter Siswi SMK Negeri 6 Makassar. Skripsi, Fakultas Ilmu Keolahragaan, Universitas Negeri Makassar.

Eka Sari Oktaviani, E. S. (2013). Artikel Tinju. Diakses dari http://ekasario.blogspot.co.id/2013/09/artikel-tinju.html.

Kirom, M. H. (2014). Teknik Dasar Pukulan dalam Tinju. Diakses dari http://labonlen.blogspot.co.id/2014/03/teknik-dasar-pukulan-dalam-tinju.html.

Riswan. (2014). Artikel Olahraga Tinju. Diakses dari http://artikelolahraga89.blogspot.co.id/2014/04/artikel-olahraga tinju.html. 